Doi: $10.26558 / \mathrm{ijcst} .366687$

International Journal of Crop Science and Technology
IJCST

\title{
Determination of Relationships Between Drought Resistance Parameters and Irrigation Regimes in Prunus mahaleb L. Rootstocks
}

\author{
$\underline{\text { İ. Kürșat ÖZYURT }}^{1^{*}}$ Yaşar AKÇA ${ }^{2} \quad$ Oğuzhan AYDIN ${ }^{3}$ \\ ${ }^{1}$ Middle Black Sea Transitional Zone Agricultural Research Institute, Turkey. \\ ${ }^{2}$ Gaziosmanpaşa University, Faculty of Agriculture, Department of Horticulture, Turkey. \\ ${ }^{3}$ Middle Black Sea Transitional Zone Agricultural Research Institute, Turkey.
}

\begin{abstract}
In this study, the relationships between different irrigation regimes and drought resistance parameters were investigated in Prunus mahaleb L. Three Prunus mahaleb L. rootstocks genotypes with high rooting capacity and SL 64 clonal rootstock were used. Four different irrigation regimes were applied ( $I_{1}=$ completing water deficient to field capacity, $I_{2}=70 \%$ of $I_{1}$ application, $I_{3}=40 \%$ of $I_{1}$ application, $I_{4}=10 \%$ of $I_{1}$ application) in drought tests. We found significant positive important relationships (correlation coefficient) between increased irrigation regimes and leaf area (0.606), plant length (0.585), plant diameter (0.584), chlorophyll a (0.485), chlorophyll b $(0.613)$, total chlorophyll (0.532), $\mathrm{pH}(0.415)$, stomata diameter $(0.558)$, stomata length $(0.538)$, stomata number $(0.856)$. It is found negative significant relationships between increased irrigation regimes and abscisic acid content $(-0.344)$ and it is calculated insignificant relationships total sugar $(-0.064)$ and total starch $(0.008)$.

Keywords: Drought stress, Correlation coefficient, Abscisic acid, Stoma
\end{abstract}

\section{INTRODUCTION}

It is possible that there are different genotypes in the Prunus mahalep rootstocks known as resistant to drought stress, (Akça, 2000). Prunus mahalep rootstocks are used for arid and calcareous soils in cherry and sour cherry cultivation. In arid climatic conditions, water demand increases during the growth periods of plants. For this reason, the researches of drought stress should be done in the plants. Also, it is important to develop the resistant to drought varieties and rootstocks. In order to determine resistant to drought varieties and to utilize these characteristics of plants, it is firstly necessary to understand the basic principles of drought stress on plants (Kaynaş and Eriş, 1995). The drought stress can be seen in the amount of water that the plants lose by transpiration more than the amount of water taken from the soil. One of the abiotic stress conditions that most affect the growth and development of plants is drought (Farooq et al., 2009). Physiological, morphological and biochemical reactions are observed in plants in drought stress situations. Variables such as plant growth, chlorophyll content, ABA and total starch are examined in drought stress studies. In this study, the relationships between some parameters used in drought stress physiology in water-restricted mahaleb rootstocks were investigated.

\section{MATERIAL AND METHOD}

\section{Material}

The research was conducted in the greenhouse. In the experiment, three new Prunus mahaleb L. genotypes (60TM06, 60TM30, 60TM31) with high rooting rate and clone SL64 parent were used. A pot with

*kursatozyurt@hotmail.com 
a volume of 40 liters was placed in a ratio of 1: $2: 1: 0,5$ sand: loamy soil: peat: $31.1 \mathrm{~kg}$ of farm fertilizer mixture and plants are planted. The salinity content of the irrigation water in the experiment was determined to be 0,572 $\mathrm{dS} / \mathrm{m}, \mathrm{pH}$ value 7,45 and salinity class T2A1. Two olds rootstock planted in early April.

\section{METHOD}

\section{Determination of Irrigation Amount and Irrigation Time}

In the study, pots were weighed and soil samples were taken from the pot to determine the amount and time of irrigation water. The field capacity (\%), wilting point (\%) and available water, (\%) values of the soil samples were determined under laboratory conditions. The beneficial moisture of soil was monitored and irrigated by determining potted field capacity weight (WTK), wilting point weight (WSN) and available water useful moisture weight (WFN) (Düzdemir, 2009). The irrigation time began to squeeze when $60 \%$ of the soil available water beneficial moisture content was consumed. Until the drought test started, the plants were watered at useful moisture levels. The irrigation was held between 1 July and 1 September. The amount of irrigation water was given at $100 \%$ (I1), $70 \%$ (I2), $40 \%$ (I3) and $10 \%$ (I4) levels of field capacity.

\section{Test Plan}

In the study, according to the design of random blocks, three repetitions and three pots were used each time. Correlation analysis was applied to the obtained data in SPSS statistical package program.

\section{The Parameters Evaluated in Drought Tolerance Tests}

The relationships between leaf chlorophyll content (chlorophyll a, chlorophyll b, total chlorophyll), leaf abscisic acid (ABA) content, number of stomata, stoma length, stoma width, total sugar and total leaf weight, leaf area, shoot length, starch contents were determined by correlations analysis.

\section{Results and Discussion}

The correlation coefficients between the four irrigation topics $\left(\mathrm{I}_{1}, \mathrm{I}_{2}, \mathrm{I}_{3}, \mathrm{I}_{4}\right)$ and the parameters assessed in the tolerance test for drought are presented in Table 1.

In our study, it was also found that $\mathrm{ABA}$ content decreased considerably in decreasing water deficients. The correlation coefficient between irrigation and ABA was $-0.344 \pm$ 0.017 (Table 1). Leaf ABA content of peaches decreased due to increased water stress (Kaynaş and Eriş 1995).

We have found important correlation coefficient in between $\mathrm{pH}$ and leaf area, shoot length, shoot diameter, shoot width, chlorophyll b content, stoma width, stoma length, number of stomata and total sugar. But, statistically significant negative relationships were found between ABA, chlorophyll a, total chlorophyll and total amount of starch. The most important correlation coefficient $(0,482 \pm 0,001)$ were found in between leaf $\mathrm{pH}$ value and shoot length (Table 1).

Positive relationships were found between with leaf area and the length of shoot, chlorophyll a, chlorophyll b, total chlorophyll, stoma width, stoma length, number of stomata, shoot diameter width, and total amount of starch. Also, negative relationships were found in between ABA and total sugar content. The highest significant correlation coefficient $(0.780 \pm 0,000)$ were found in between leaf area and among the plant body width (Table 1).

When cell expansion is inhibited, leaf expansion slows down. Depending on the amount of water decreasing in the soil, the leaf area is shrinking and the transpiration area and water consumption are decreased (Akman et al., 2004). 
The statistically significant positive correlations coefficients were found between the length of the shoot and the content of chlorophyll a, chlorophyll b, total chlorophyll, stoma width, stoma length, number of stoma, shoot width and total starch amount. Also, the statistically significant negative relationships were found in between ABA content and, total sugar content. The highest significant correlation coefficient $(0,767 \pm 0,00)$ were found between the shoot length and the shoot width. With the plant body; the positive statistically significant relationships were found between the content of chlorophyll a, chlorophyll b, total chlorophyll, stoma width, stoma length, number of stoma and total amount of starch. However, the statistically significant negative relationships between were determined in between ABA content and total sugar content (Table 1).

The statistically significant positive relationships between were determined in chlorophyll a content and chlorophyll b content, total chlorophyll, stoma width, stoma length, number of stoma and total starch, total sugar. Significant indications of plant-soil-water relations; leaf coloring, leaf drying, and changes observed in the leaves (Wenkert, 1980). In water stress, chlorophyll synthesis is reduced in leaves, chlorophyll breaks down and yellowing occurs in leaf color (Vardar, 1972 ; Kramer and Kozlowski, 1979).

The significant negative correlations coefficient were found between the total chlorophyll content and stoma width, stoma length, number of stoma and total starch. The highest correlation coefficient $(0,611 \pm 0,00)$ was found between the total chlorophyll content and 0,611 $\pm 0,00$ stoma number (Table 1). Under normal irrigation conditions, the number of stomas increased. Kaynaş and
Eriş (1995) reported that the amount of leaf chlorophyll-a, chlorophyll-b and total chlorophyll decreases in water-restricted conditions in nectarines. It is found that statistically significant correlation coefficient between number of stoma and stoma width, stoma size and total starch content. We found important positive relationships between stoma length and stoma width and total sugar content but there was significant negative correlations with the total starch content.

It is found that important relationship between stomata density in the leaves, the movement of stomata between and water consumptions and plant-water balance (Abak and Yanmaz, 1980). Xu and Zhou (2008) stated that the stoma size is reduced by drought stress.

In our study, the relationships between total sugar and total starch and other parameters were found to be statistically insignificant. Some studies have shown that drought stress can lead to an increase in the amount of sucrose, glucose and fructose in the leaves of some plant species (Turner et al., 1978, Jones et al., 1980; Wang et al., 1991).

\section{RESULTS}

Inadequate shoot formation and root development are the first symptoms of water stress in plants. In conditions of drought stress, plants firstly slow down stem extension and improve root development to reach adequate water. Depending on the severity and duration of drought stress, stem and root growth slows down, leaf area and leaf number decrease. Some leaves turn yellow and fall (Anjum et al., 2011).

According to the results obtained in our research, significant relationships between irrigation quantity, shoot length and plant body diameter were determined. Plants 
synthesize substances that play a role in the protection of cell turgor balance in drought stress. These compounds are asparagine, proline, glycine, betaine, organic acids and carbohydrates. In drought stress conditions, ABA plays a role in the closure of stomata, the reduction of chlorophyll synthesis and the regulation of the photosynthesis mechanism (Anjum et al., 2011).

It is known that the amount of water given to the plants increases the plant growth (Anjum et al., 2011). According to the results obtained in our research; there was a statistically significant relationship between irrigation and leaf area, shoot length, shoot diameter, chlorophyll a, chlorophyll b, total chlorophyll, $\mathrm{pH}$, stoma width, stoma length, stoma number and total starch.

Statistically significant negative relationships were found between abscisic acid and total sugar amount. As the amount of irrigation water given to the plants increased, abscisic acid and total sugar content of plant decreased. According to this result, plants in drought stress are increasing abscisic acid and total sugar synthesis in order to increase tolerance to drought stress.

\section{REFERENCES}

Abak, K., Yanmaz, R. 1980, Domates ve Fasulye Fidelerinin Yapraklarında Toplam ve Açık Stoma Sayısı Üzerine GA3, CEPA B-9 ve CCC'nin Etkileri. TÜBITTAK VII. Bilim Kongresi, Adana.

Akça, Y. 2000. Meyve Türlerinde Kullanılan Anaçlar. Tokat. DC: GOP Üniversitesi Ziraat Fakültesi Yayınları.

Akman, Y., Keteoğlu, O., Kurt, L., Güney, K. 2004. Bitki Ekolojisi. Türkiye. DC: Palme Yayıncilık.
Anjum SA, Xie X, Wang L, Saleem MF, Man C, Lei W. 2011. Morphological, physiological and biochemical responses of plants to drought stress. African Journal of Agricultural Research, 6: 2026-2032.

Düzdemir, O., Ünlükara, A., Kurunç, A. 2009. Response of cowpea to salinity and irrigation regims. Journal of Crop and Horticultural Science, 37:271-280.

Farooq, M., Wahid, A., Kobayashi, N., Fujita, D., Basra, SMA. 2009. Plant dorught stress: effects, mechanisms and management. Agronomy for Sustainable Development 29: 185-212.

Jones, MMG., Osmond, CD., Turner, NC. 1980. Accumulation of solutes in leaves of sorghum and sunflower in response to water deficts. Australian Journal of Plant Physiology, 7: 193-205.

Kaynaş, N., Eriş, A. 1995. Bazı Nektarin Çesitlerinde Toprak Su Noksanlığının Biyokimyasal Degişimler Üzerine Etkileri. Tr.J. of Agriculture and Forestry. 22: 35-4.

Kramer, PS., Kozlowski, TT. 1979. Physiology of Woody Plants. New York, DC: Academic Press.

Osmond, CB., Austin, MP., Berry, JA., Billings, WD., Boyer, JS., Dacey, JWH., Nobel, PS., Smith, SD., Winner WE. 1987. Stress physiology and the distribution of plants. Bioscince, 37 (1): 38-48.

Turner, NC., Begg, JE., Tonnet, ML. 1978. Osmotic adjusment of sorghum and sunflower crops in response to water potential at which stomata close. Australian Journal of Plant Physiology, 5(5): 597-608.

Vardar, 1972. Bitki Fizyolojisi Ders Notlart. İzmir, DC: Ege Üniversitesi Fen Fakültesi Yayınları.

Wang, Z., Qubedeaux, B., Stutte, GW. 1991. Osmotic adjusment: effect on sucrosephosphte syntheses activity in Phseolus 
vulgaris. Physiologia Plantarum, 81: 3744.

Wenkert, 1980. Measurement of Tissue Osmotic Pressure. Ohio, DC: United States Department of Agriculture.

Xu, Z., Zhou, G. 2008. Responses of Leaf Stomatal Density to Water Status and its Relationship with Photosynthesis in a Grass. Journal Exper. Botany, 59 (12): 3317-3325. 
Table 1. The Correlation coefficients between drought resistance parameters and irrigation regimes In Prunus mahaleb L. rootstocks

\begin{tabular}{|c|c|c|c|c|c|c|c|c|c|c|c|c|c|c|c|}
\hline & & (1) & (2) & (3) & (3) & (4) & (5) & $(/ 9$ & (8) & (9) & (10) & (11) & (12) & (13) & (14) \\
\hline \multirow[t]{2}{*}{ Irrigation regimes (1) } & Correlation cofficient & 1 & $.415^{* *}$ & $.606^{* *}$ & $.585^{* *}$ & $.584 * *$ & $.485^{* *}$ & $.613^{* *}$ & $.532 * *$ & $-.344^{*}$ & $.856^{* *}$ & $.538^{* *}$ & $.558^{* *}$ & -0.064 & 0.008 \\
\hline & $\mathrm{P}$ & & 0.003 & 0 & 0 & 0 & 0 & 0 & 0 & 0.017 & 0 & 0 & 0 & 0.663 & 0.955 \\
\hline \multirow[t]{2}{*}{$\mathrm{pH}(2)$} & Correlation cofficient & $.415^{* *}$ & 1 & $.475^{* *}$ & $.482 * *$ & $.343^{*}$ & -0.03 & 0.089 & -0.005 & -0.03 & $.381^{* *}$ & $.296^{*}$ & 0.125 & 0.095 & -0.087 \\
\hline & $\mathrm{P}$ & 0.003 & & 0.001 & 0.001 & 0.017 & 0.837 & 0.549 & 0.975 & 0.842 & 0.008 & 0.041 & 0.396 & 0.521 & 0.554 \\
\hline \multirow[t]{2}{*}{ Leaf area (3) } & Correlation cofficient & $.606^{* *}$ & $.475^{* *}$ & 1 & $.751 * *$ & $.780 * *$ & $.297^{*}$ & $.333^{*}$ & $.316^{*}$ & -0.179 & $.674 * *$ & $.414 * *$ & $.485^{* *}$ & -0.066 & 0.108 \\
\hline & $\mathrm{P}$ & 0 & 0.001 & & 0 & 0 & 0.041 & 0.021 & 0.029 & 0.222 & 0 & 0.003 & 0 & 0.657 & 0.463 \\
\hline \multirow[t]{2}{*}{ Shoot length (4) } & Correlation cofficient & $.585^{* *}$ & $.482 * *$ & $.751 * *$ & 1 & $.767 * *$ & 0.136 & 0.197 & 0.152 & -0.217 & $.611^{* *}$ & $.380 * *$ & $.414 * *$ & -0.249 & 0.164 \\
\hline & $\mathrm{P}$ & 0 & 0.001 & 0 & & 0 & 0.357 & 0.179 & 0.302 & 0.139 & 0 & 0.008 & 0.003 & 0.088 & 0.266 \\
\hline \multirow[t]{2}{*}{ Plant diameter (5) } & Correlation cofficient & $.584 * *$ & $.343^{*}$ & $.780^{* *}$ & $.767 * *$ & 1 & 0.221 & 0.269 & 0.24 & $-.313^{*}$ & $.583^{* *}$ & $.374 * *$ & $.436^{* *}$ & -0.208 & 0.053 \\
\hline & $\mathrm{P}$ & 0 & 0.017 & 0 & 0 & & 0.131 & 0.064 & 0.101 & 0.03 & 0 & 0.009 & 0.002 & 0.156 & 0.721 \\
\hline \multirow[t]{2}{*}{ Chlorophylla (6) } & Correlation cofficient & $.485^{* *}$ & -0.03 & $.297^{*}$ & 0.136 & 0.221 & 1 & $.838^{* *}$ & $.990^{* *}$ & -0.116 & $.540^{* *}$ & 0.218 & $.535^{* *}$ & 0.005 & 0.002 \\
\hline & $\mathrm{P}$ & 0 & 0.837 & 0.041 & 0.357 & 0.131 & & 0 & 0 & 0.43 & 0 & 0.136 & 0 & 0.971 & 0.992 \\
\hline \multirow[t]{2}{*}{ Chlorophyllb (7) } & Correlation cofficient & $.613^{* *}$ & 0.089 & $.333^{*}$ & 0.197 & 0.269 & $.838^{* *}$ & 1 & $.903^{* *}$ & -0.144 & $.611 * *$ & 0.262 & $.588^{* *}$ & -0.122 & 0.028 \\
\hline & $\mathrm{P}$ & 0 & 0.549 & 0.021 & 0.179 & 0.064 & 0 & & 0 & 0.328 & 0 & 0.071 & 0 & 0.408 & 0.848 \\
\hline \multirow[t]{2}{*}{ Total chlorophyll (8) } & Correlation cofficient & $.532 * *$ & -0.005 & $.316^{*}$ & 0.152 & 0.24 & $.990 * *$ & $.903 * *$ & 1 & -0.132 & $.574 * *$ & 0.242 & $.569^{* *}$ & -0.018 & 0.006 \\
\hline & $\mathrm{P}$ & 0 & 0.975 & 0.029 & 0.302 & 0.101 & 0 & 0 & & 0.371 & 0 & 0.098 & 0 & 0.905 & 0.967 \\
\hline \multirow[t]{2}{*}{$\overline{\mathrm{ABA}(9)}$} & Correlation cofficient & $-.344 *$ & -0.03 & -0.179 & -0.217 & $-.313^{*}$ & -0.116 & -0.144 & -0.132 & 1 & -0.199 & -0.243 & -0.277 & -0.131 & -0.117 \\
\hline & $\mathrm{P}$ & 0.017 & 0.842 & 0.222 & 0.139 & 0.03 & 0.43 & 0.328 & 0.371 & & 0.176 & 0.096 & 0.057 & 0.376 & 0.426 \\
\hline \multirow[t]{2}{*}{ Stoma number (10) } & Correlation cofficient & $.856^{* *}$ & $.381 * *$ & $.674^{* *}$ & $.611 * *$ & $.583 * *$ & $.540 * *$ & $.611^{* *}$ & $.574 * *$ & -0.199 & 1 & $.538 * *$ & $.617 * *$ & -0.098 & 0.004 \\
\hline & $\mathrm{P}$ & 0 & 0.008 & 0 & 0 & 0 & 0 & 0 & 0 & 0.176 & & 0 & 0 & 0.509 & 0.977 \\
\hline \multirow[t]{2}{*}{ Stoma length (11) } & Correlation cofficient & $.538^{* *}$ & $.296^{*}$ & $.414^{* *}$ & $.380^{* *}$ & $.374 * *$ & 0.218 & 0.262 & 0.242 & -0.243 & $.538^{* *}$ & 1 & 0.158 & 0.048 & -0.087 \\
\hline & $\mathrm{P}$ & 0 & 0.041 & 0.003 & 0.008 & 0.009 & 0.136 & 0.071 & 0.098 & 0.096 & 0 & & 0.283 & 0.744 & 0.557 \\
\hline \multirow[t]{2}{*}{ Stoma width (12) } & Correlation cofficient & $.558^{* *}$ & 0.125 & $.485^{* *}$ & $.414 * *$ & $.436^{* *}$ & $.535^{* *}$ & $.588^{* *}$ & $.569^{* *}$ & -0.277 & $.617^{* *}$ & 0.158 & 1 & -0.043 & 0.067 \\
\hline & $\mathrm{P}$ & 0 & 0.396 & 0 & 0.003 & 0.002 & 0 & 0 & 0 & 0.057 & 0 & 0.283 & & 0.771 & 0.651 \\
\hline \multirow[t]{2}{*}{ Total sugar content (13) } & Correlation cofficient & -0.064 & 0.095 & -0.066 & -0.249 & -0.208 & 0.005 & -0.122 & -0.018 & -0.131 & -0.098 & 0.048 & -0.043 & 1 & -0.224 \\
\hline & $\mathrm{P}$ & 0.663 & 0.521 & 0.657 & 0.088 & 0.156 & 0.971 & 0.408 & 0.905 & 0.376 & 0.509 & 0.744 & 0.771 & & 0.126 \\
\hline \multirow[t]{2}{*}{ Total starch content (14) } & Correlation cofficient & 0.008 & -0.087 & 0.108 & 0.164 & 0.053 & 0.002 & 0.028 & 0.006 & -0.117 & 0.004 & -0.087 & 0.067 & -0.224 & 1 \\
\hline & $\mathrm{P}$ & 0.955 & 0.554 & 0.463 & 0.266 & 0.721 & 0.992 & 0.848 & 0.967 & 0.426 & 0.977 & 0.557 & 0.651 & 0.126 & \\
\hline
\end{tabular}

